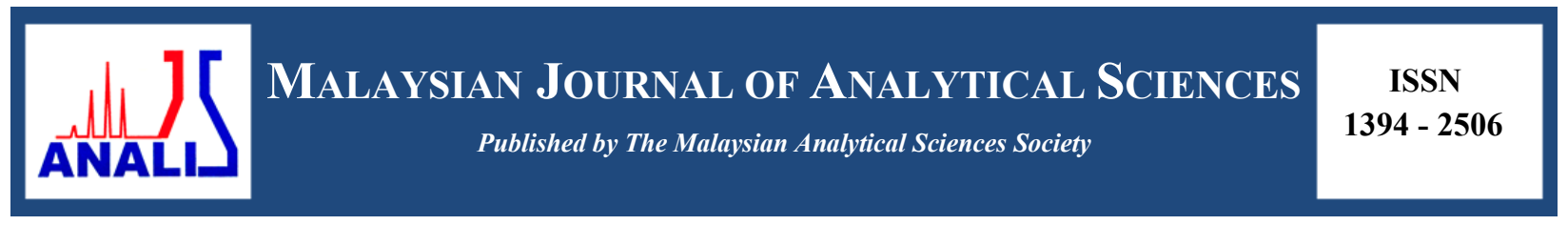

\title{
CORRELATION BETWEEN PROTON CONDUCTIVITY, HYDROPHILICITY, AND THERMAL STABILITY OF CHITOSAN/MONTMORILLONITE COMPOSITE MEMBRANE MODIFIED GPTMS AND THEIR PERFORMANCE IN DIRECT METHANOL FUEL CELL
}

\author{
(Hubungan antara Kekonduksian Proton, Sifat Hidrofil dan Kestabilan Termal atas Membran
} Komposit Kitosan/Montmorillonit dengan Modifikasi GPTMS dan Prestasinya dalam Sel Bahan Api Metanol Langsung)

\author{
Mochammad Purwanto ${ }^{1,2}$, Lukman Atmaja ${ }^{3 *}$, M.T. Salleh ${ }^{2}$, Mohamad Azuwa Mohamed ${ }^{2}$, Juhana Jaafar ${ }^{2}$, \\ Ahmad Fauzi Ismail $^{2}$, Mardi Santoso ${ }^{3}$, Nurul Widiastuti ${ }^{3}$ \\ ${ }^{1}$ Institut Teknologi Kalimantan, Kampus ITK Karang Joang, Balikpapan 76127, Indonesia \\ ${ }^{2}$ Advanced Membrane Technology (AMTEC) Research Centre, \\ Universiti Teknologi Malaysia, 81310 UTM Johor Bahru, Johor, Malaysia \\ ${ }^{3}$ Department of Chemistry, \\ Institut Teknologi Sepuluh Nopember, ITS Sukolilo, Surabaya 60111, Indonesia \\ *Corresponding author: lukman_at@chem.its.ac.id
}

Received: 26 August 2016; Accepted: 8 January 2017

\begin{abstract}
Chitosan based inorganic hybrid membrane is a promising organic-inorganic hybrids for the development of high performance proton exchange membrane (PEM). The immobilization of modified montmorillonite (MMT) using GPTMS within chitosan matrix would possess superior physicochemical characteristics due to more hydrogen bonding formation introduced by GPTMS. Therefore, higher number hydrogen bond formation can be expected in Ch/MMT-GPTMS membrane rather than in pure Ch membrane. A fully hydrated membrane at elevated temperatures is desirable for efficient proton conduction in the membranes. It remains a critical challenge to maintain proper hydration of the membranes for the operation of the direct methanol fuel cell (DMFC). The microstructure obtained by SEM for composites showed that filler was successfully incorporated and relatively well dispersed in the chitosan polymer matrix. The role of surface modification of MMT filler by GPTMS have increase the functional group that can form hydrogen bonding which suitable for interaction with water. High water uptake is favourable for high performance PEM to facilitate great numbers of protons hopping and diffusion through the membrane. In addition, greater hydrogen bonding formation would lead to the tighter packing of composite membrane, resulting in higher bonding strength and higher thermal resistance. The Ch/MMT-GPTMS composite membrane with $5 \mathrm{wt} \%$ filler loading exhibited the best proton conductivity are $4.66 \mathrm{mScm}^{-1}$, with water contact angle value of $64.73^{\circ}$. A maximum power density of $0.24 \mathrm{mWcm}^{-2}$ was obtained with a $2 \mathrm{M}$ methanol feed. The relationship of water contact angle, water upake, membrane swelling, thermal stability, and proton conductivity shown suitable trend, it means that all quality of them are related to the hydrophilicity properties.
\end{abstract}

Keywords: chitosan, montmorillonite, (3-glycidoxypropyl) trimethoxysilane, direct methanol fuel cel

Abstrak

Kitosan berasaskan membran hibrid tak organik ialah kacukan organik-tak organik yang menjanjikan pembangunan pertukaran proton membran berprestasi tinggi (PEM). Montmorillonit (MMT) pegun diubahsuai menggunakan GPTMS dalam matriks 


\title{
Purwanto et al: CORRELATION BETWEEN PROTON CONDUCTIVITY, HYDROPHILICITY, AND THERMAL STABILITY OF CHITOSAN/MONTMORILLONITE COMPOSITE MEMBRANE MODIFIED GPTMS AND THEIR PERFORMANCE IN DIRECT METHANOL FUEL CELL
}

\begin{abstract}
kitosan akan mempunyai ciri-ciri fiziko-kimia unggul kerana lebih pembentukan ikatan hidrogen yang diperkenalkan oleh GPTMS. Oleh itu, pembentukan jumlah ikatan hidrogen yang lebih tinggi boleh dijangka pada membran Ch/MMT-GPTMS bukannya pada membran Ch tulen. Setiap membran terhidrat sepenuhnya pada suhu tinggi adalah diperlukan untuk pengaliran proton cekap dalam membran. Ia kekal sebagai cabaran kritikal untuk mengekalkan penghidratan membran untuk operasi sel bahan api metanol langsung (DMFC). Mikrostruktur diperolehi melalui SEM untuk komposit menunjukkan bahawa pengisi telah berjaya digabungkan dan tersebar di dalam matriks polimer kitosan. Peranan pengubahsuaian permukaan MMT pengisi oleh GPTMS telah meningkatkan kumpulan berfungsi yang boleh membentuk ikatan hidrogen yang sesuai untuk berinteraksi dengan air. Pengambilan air yang tinggi adalah baik untuk PEM yang berprestasi tinggi bagi membantu proton bergerak dan penyebaran melalui membran. Di samping itu, pembentukan ikatan hidrogen yang lebih besar akan membawa kepada pembungkusan membran komposit yang lebih ketat, menyebabkan kekuatan ikatan dan rintangan haba yang lebih tinggi. Membran komposit $\mathrm{Ch} /$ MMT-GPTMS dengan $5 \%$ berat pengisi mewujudkan kekonduksian proton terbaik iaitu $4.66 \mathrm{mScm}^{-1}$, dengan nilai sudut sentuhan air ialah $64.73^{\circ}$. Ketumpatan kuasa maksimum ialah $0.24 \mathrm{mWcm}^{-2}$ telah diperolehi dengan suapan $2 \mathrm{M}$ metanol. Hubungan sudut sentuhan air, serapan air, pengembangan membran, kestabilan haba, dan kekonduksian proton menunjukkan corak yang sesuai, ia bermaksud semua kualiti yang terhasil adalah berkaitan sifat hidrofilik.
\end{abstract}

Kata kunci: kitosan, montmorillonit, (3-glisidoksipropil) trimetoksisilana, sel bahan api metanol langsung

\section{Introduction}

Fuel cells are considered as green, reliable and highly efficient power generation technology in the current century. Among the different types of fuel cells, direct methanol fuel cell (DMFC) are promising candidates for portable devices or transportation applications in view of their high energy density, simplified system design, low emission, low temperature and pressure operation and high efficiency [1,2]. Polymer electrolyte membranes (PEM), a crucial component in the DMFC separating the cathode and anode, function as proton conductor as well as methanol separator between the cathode and anode [3]. In fact, the performance of DMFC is profoundly connected to PEM, wherein the electrochemically generated protons transport from anode to cathode electrodes. Perfluorosulfonic acid membranes $\left(\right.$ Nafion $\left.^{\circ}\right)$ are widely used as PEM for DMFC applications, owing to good chemical and thermal resistance and high ionic conductivity [4,5]. However, these membranes suffer from drastic high methanol diffusion, high cost and rapid dehydration with decreasing proton conductivity at high temperatures. The high methanol diffusion causes loss of fuel, reduced fuel efficiency, reduced cathode voltage and excess thermal load in the cell $[4,6,7]$.

Chitosan is considered to be the second most abundant polysaccharide in the world after cellulose which can be renewed and produced by utilizing marine waste such as shrimp, crab, lobster, and fish shells [8,9]. Chitosan can also be prepared from fungal cell walls via fermentation technology [10]. Chitosan is a polyaminosaccharide with good mechanical strength, biodegradable, and nontoxic properties $[11,12]$. Chitosan is not directly available in nature, however, it can be easily generated through the process of deacetylation of chitin by a strong alkali [8]. In the recent years, the comprehensive utilization of chitosan as bio-based polymer has drawn elevated attention for various functional hybrid materials with tremendous properties for various applications such as medicine, pharmaceutical, food industries, waste water treatment and energy [13-17].

It has been reported that the reinforcement of nanomaterial in bio-polymeric matrices has greatly improved the physicochemical, mechanical and thermal stability characteristic of resultants bio-polymer nanocomposites [18-20]. Recently, the incorporation of layered silicates and in particular montmorillonite (MMT) in chitosan has been extensively studied [21-24]. The use of MMT as a filler in bio-polymer is interesting due to its environmental and economic importance. MMT has several advantages including easy to obtain, having a large specific surface area, chemical resist, having strong absorption capability, and having good cation exchange capacity, and having good adhesive capability [25-28].

MMT as an inorganic material cannot collaborate perfectly with organic polymer, because the surface layer of montmorillonite cannot interact maximally with the organic portion of the polymer. Organophilization process is one of the promising methods to improve the interaction of MMT in polymer matrices $[29,30]$. Huang and coworkers prepared carboxymethyl chitosan/organically MMT with enhanced thermal stability and antimicrobial activity with complexation with copper ion [22]. Wang et al. developed an organic-inorganic composite using chitosan as the polymer matrix and zeolite as inorganic filler [31]. Their study indicated that by using (3- 
glycidoxypropyl) trimethoxysilane (GPTMS) to modify the zeolite surface, the new developed composite membrane was able to achieve denser and high thermal stability.

In this study, we prepared chitosan/MMT-GPTMS composite membrane by utilizing dried shrimp shell powder as chitosan source and acetic acid as solvent. The surface modification process of MMT using (3-glycidoxypropyl) trimethoxysilane (GPTMS) would provide excellent compatibility with chitosan membrane. The immobilization of modified MMT using GPTMS within chitosan matrix would possess superior psychochemical characteristics due to more hydrogen bonding formation introduced by GPTMS. Therefore, higher number hydrogen bond formation can be expected in $\mathrm{Ch} / \mathrm{MMT}$-GPTMS membrane rather than in pure $\mathrm{Ch}$ membrane. A fully hydrated membrane at elevated temperatures is desirable for efficient proton conduction in the membranes. It remains a critical challenge to maintain proper hydration of the membranes for the operation of the DMFC. The aim of this study is to analyse a relationship between proton conductivity, hydrophilicity, and thermal stability of chitosan/montmorillonite composite membrane modified GPTMS as the electrolyte membrane for direct methanol fuel cell. The morphological structure and functional groups was analysed by SEM and FTIR. The thermal stability TGA/DTG and The hydrophilicity properties was investigated by water contact angle, water uptake (WU) and membrane swelling (MS). The proton conductivity, methanol permeability, DMFC single cell are carried out to determine the overall membrane performance for DMFC applications.

\section{Materials}

\section{Materials and Methods}

Shrimp shell waste of Penaeusmonodon was used the chitosan source. Montmorillonite (MMT K-10, S.A 220 - 270 $\mathrm{m}^{2} / \mathrm{g}$ ) powder, (3-glycidoxypropyl) trimethoxysilane (GPTMS)and phosphotungstic acid (PTA, $\mathrm{H}_{3} \mathrm{PW}_{12} \mathrm{O}_{40} . \mathrm{xH}_{2} \mathrm{O}$, MW: 2880.05) were purchased from Sigma-Aldrich. Sodium hydroxide $(\mathrm{NaOH})$, hydrochloric acid $(\mathrm{HCl})$, methanol $(\mathrm{MeOH})$, acetic acid, in pure analytical grade were purchased from Merck. The distilled water was used throughout the study.

\section{Extraction of chitosan matrix and MMT modification}

Chitosan was extracted according to the approach reported in the literature [32], with four step process includes preparation, deproteination, demineralization and deacetylation. First step, shrimp shell waste was driedat $60{ }^{\circ} \mathrm{C}$ and then it was grinded until it became dried shrimp shell powder. Second step, dried shrimp powder was added into $3.5 \% \mathrm{NaOH}$ solution with a ratio of $1: 10(\mathrm{w} / \mathrm{v})$ under continuous stirring for 2 hours at $65^{\circ} \mathrm{C}$. Then, the mixture was filtered and the outcome was washed until $\mathrm{pH} 7$ and dried at $105{ }^{\circ} \mathrm{C}$. Third step, the dried powder was then demineralized using $1 \mathrm{M} \mathrm{HCl}$, stirred for 30 minutes at $65^{\circ} \mathrm{C}$ with a ratio of $1: 15(\mathrm{w} / \mathrm{v})$, washed, and dried. The results of demineralization process is dry powder form, called chitin. The chitin powder obtained was then run through the deacetylation process in last process, using $50 \% \mathrm{NaOH}$ solution, stirred for four hours at $120{ }^{\circ} \mathrm{C}$ with a ratio of 1:10 (w/v), washed, and dried until it became dried powder called chitosan.

The modification of MMT sample was performed using the surface hydroxyl groups of MMT by dehydration process and condensation with GPTMS. MMT powder, GPTMS and toluene were mixed in a reactor with weight ratio 1:2:20. The reaction was carried out at refluxing temperature of toluene $\left(110^{\circ} \mathrm{C}\right)$ and stirred for 24 hours. After being washed with ethanol for three times, the sample was soaked in a solution of $0.1 \mathrm{M} \mathrm{HCl}$ for 24 hours at room temperature. The precipitate then was filtered and washed with demineralized water until neutral. Finally, the precipitate was dried in the oven at $100{ }^{\circ} \mathrm{C}$ for four hours. The surface-modified MMT was designated as MMTGPTMS.

\section{Membrane fabrication}

Chitosan powder was dissolved in $25 \mathrm{~mL}$ of $2 \%$ acetic acid, and stirred at $80{ }^{\circ} \mathrm{C}$ and $400 \mathrm{rpm}$. Another $25 \mathrm{~mL}$ of $2 \%$ acetic acid was used to dilute MMT-GPTMS powder and ultrasonic treatment for 30 minutes. Then, both mixtures were mixed together and stirred for 30 minutes at $80^{\circ} \mathrm{C}$. After that, the mixture was given an ultrasonic treatment for 30 minutes, stopped for 30 minutes, and then, an ultrasonic treatment was carried out again for 30 minutes. After degasification, the mixture was then caston glass panel and dried at room temperature for 48 hours. The detached membrane was then immersed in $1 \mathrm{M} \mathrm{NaOH}$ for 15 minutes before being washed with distilled water until neutral $\mathrm{pH}$ was achieved.The membrane then immersing in $2 \% \mathrm{w} / \mathrm{v}$ of PTA solution for 24 hours, and then washed 
Purwanto et al: CORRELATION BETWEEN PROTON CONDUCTIVITY, HYDROPHILICITY, AND

THERMAL STABILITY OF CHITOSAN/MONTMORILLONITE COMPOSITE MEMBRANE

MODIFIED GPTMS AND THEIR PERFORMANCE IN DIRECT METHANOL FUEL CELL

repeatedly with distilled water to remove the remaining PTA acid before being dried at room temperature for 24 hours $[33,34]$. The pristine chitosan membranes and MMT unmodified was synthesized by the same process.

\section{Membrane characterization}

Fourier Transform Infrared Spectroscopy (FTIR) was used to analyse the structure and functional group. The disk containing $0.1-0.2 \mathrm{~g}$ sample and $0.5-1.0 \mathrm{~g}$ of fine grade $\mathrm{KBr}$ was mixed and crushed into powder, and pellets were formed with a hydraulic press. All measurements were scanned within the waverange of $650-4000 \mathrm{~cm}^{-1}$. The morphological structural of the resultant material was analysed by means of Scanning Electron Microscopy (SEM) Bruker analysis. The sample powder was prepared in a pin stub holder and coated with gold before the analysis. Thermo gravimetric analysis (TGA) was carried out using a Mettler Toledo 851e TGA/DTG thermogravimetric analyser at a heating rate of $10{ }^{\circ} \mathrm{C} \mathrm{min}^{-1}$ under air flow of $30 \mathrm{~mL} \mathrm{~min}^{-1}$ from room temperature to $800{ }^{\circ} \mathrm{C}$.

Water uptake (WU) were conducted by measuring the weights of membranes under fully hydrated and completely dried conditions. A detail procedure was reported previously [31]. Water uptake was calculated using equation (1).

$$
W U(\%)=\frac{W_{w e t}-W_{d r y}}{W_{d r y}} \times 100
$$

where $W_{d r y}$ and $W_{w e t}$ are the membrane weight before and after immersion in gram, respectively. The membrane swelling (MS) was defined as follows (equation 2):

$$
M S(\%)=\frac{L_{w e t}-L_{d r y}}{L_{d r y}} \times 100
$$

where $L_{\text {wet }}$ and $L_{\text {dry }}$ are the thickness of wet and dry membranes, respectively.

The hydrophilicity property of membrane studied based on water contact angle (WCA) measurement. The water contact angle was determined by using a contact angle goniometer (OCA15Pro, Data Physics), equipped with image-processing software. This instrument was used to evaluate the degree of membrane hydrophilicity via sessile drop technique. The proton conductivity of the membrane was measured using electrochemical impedance spectroscopy (EIS), at a frequency of $1-10^{6} \mathrm{~Hz}$. The proton conductivity values were calculated by using equation (3)[34].

$$
\sigma=\frac{L}{R \times A}
$$

where $\sigma$ is proton conductivity of the membrane $\left(\mathrm{S} \mathrm{cm}^{-1}\right), L$ is the membrane $(\mathrm{cm}), A$ is the membrane surface area $\left(\mathrm{cm}^{2}\right)$, and $R$ is the membrane resistance $(\Omega)$.

Methanol permeability was determined by using a two-compartment diffusion cell. Compartment A was filled with $1 \mathrm{M} \mathrm{MeOH}$ solution and compartment $\mathrm{B}$ was filled with deionized water. The membrane was placed between compartment A and B. Samples from compartment B were taken out every 30 minutes for 3 hours, to determine its methanol concentration using High Performance Liquid Chromatography (HPLC). The methanol permeability values were determined by using equation (4) [34].

$$
P=\left(\frac{\Delta C_{B}}{\Delta t}\right)\left(\frac{L V_{B}}{A C_{A}}\right)
$$

$P$ is methanol permeability of the membrane $\left(\mathrm{cm}^{2} \cdot \mathrm{s}^{-1}\right), \Delta C_{B} / \Delta t$ is the slope variation of methanol concentration in compartment $\mathrm{B}$ as a function of time $\left(\mathrm{mol} \cdot \mathrm{L}^{-1} \cdot \mathrm{s}^{-1}\right), L$ is the thickness of the membrane $(\mathrm{cm}), V_{B}$ is the volume of the water at compartmentB $\left(\mathrm{cm}^{3}\right), A$ is the membrane surface area $\left(\mathrm{cm}^{2}\right)$, and $C_{A}$ is the concentration of methanol in the cell A $\left(\right.$ mol. $\left.\mathrm{L}^{-1}\right)$.

To evaluate the cell performance of the DMFC, a membrane electrode assembly (MEA) was made by catalystcoated membranes were sandwiched within gas diffusion layers, inside the test single cell. The Pt-Ru/C with 40 wt. $\% \mathrm{Pt}+20 \mathrm{wt} \% \mathrm{Ru} / \mathrm{C}$ and the $\mathrm{Pt} / \mathrm{C}$ catalyst with $20 \mathrm{wt} . \% \mathrm{Pt}$ were used as the anodic and cathodic catalyst, 
respectively. The active area of the cells was $2.5 \mathrm{~cm}$ x $2.5 \mathrm{~cm}$. The MEA was hot-pressed at $105{ }^{\circ} \mathrm{C}$ and $5 \mathrm{MPa}$ for 1 min. The performance of the single cell was measured at room temperature with a Fuel Cell Test Autolab instrument. $2 \mathrm{M} \mathrm{MeOH}$ solution with a flow rate of $20 \mathrm{mLmin}^{-1}$ and oxygen with a flow rate of $0.5 \mathrm{Lmin}{ }^{-1}$ were used [35].

\section{Biopolymer extraction and modification process}

\section{Results and Discussion}

Figure 1 shows the FTIR spectra of chitin and chitosan. The peak at $3514 \mathrm{~cm}^{-1}$ described of stretching vibration $-\mathrm{OH}$ group and as seen as the characteristic peaks of the chitin which is at $3298,3155,1579 \mathrm{~cm}^{-1}$ derived from stretching vibration group $\mathrm{NH}\left(-\mathrm{NHCOCH}_{3}\right)$ and at $2970 \mathrm{~cm}^{-1}$ for absorption of a methyl group $\left(-\mathrm{CH}_{3}\right)$, but lost in the spectra of chitosan, however presence overlapping of stretching vibration $-\mathrm{OH}$ and $-\mathrm{NH}$ group at $3508 \mathrm{~cm}^{-1}$. The characteristic of chitosan shown the reduce of the peak at 1670 and $1622 \mathrm{~cm}^{-1}$ attributed from stretching vibration of $\mathrm{C}=\mathrm{O}$ group on the cluster $\mathrm{NHCOCH}_{3}$ chitin, shown that the removal of the acetyl group into the amine group due to the process of deacetylation. This phenomenon was supported by the loss of a methyl group $\left(-\mathrm{CH}_{3}\right)$ from the amide $\left(-\mathrm{NHCOCH}_{3}\right)$ which are known from the absorption loss at $2970 \mathrm{~cm}^{-1}$. The typical characteristic of chitosan is visible at $1662 \mathrm{~cm}^{-1}$ shows the bending vibration of $\mathrm{NH}$ amine $\left(-\mathrm{NH}_{2}\right)$ [36]. The peaks at 2945,1429 and $929 \mathrm{~cm}^{-1}$ in chitosan spectra assigned to stretching vibration of methylene $-\mathrm{CH}_{2}-, \mathrm{C}-\mathrm{N}$ stretching vibration, and buckling vibration -C-O-C- showed glucopyranose ring, respectively, similar peak also presence in chitin spectra.

The functional group analysis of MMT before and after modification using FTIR sre presented in Figure 1. Two peaks at 3440 and $1640 \mathrm{~cm}^{-1}$ corresponded to the $-\mathrm{OH}$ stretching and bending vibrations of $\mathrm{H}-\mathrm{O}-\mathrm{H}$ on the MMT surface, respectively. The GPTMS modification has reduced the intensity of -OH stretching bond vibration of pure MMT, as a result of the consumption of the MMT hydroxyl groups by condensing with the silanol groups, and meanwhile the surface of the MMT occurred decreasing of the water adsorption [33]. The characteristic peaks at $2940 \mathrm{~cm}^{-1}$ is corresponded to $\mathrm{C}-\mathrm{H}$ valence vibration for epoxy ring from GPTMS structure.

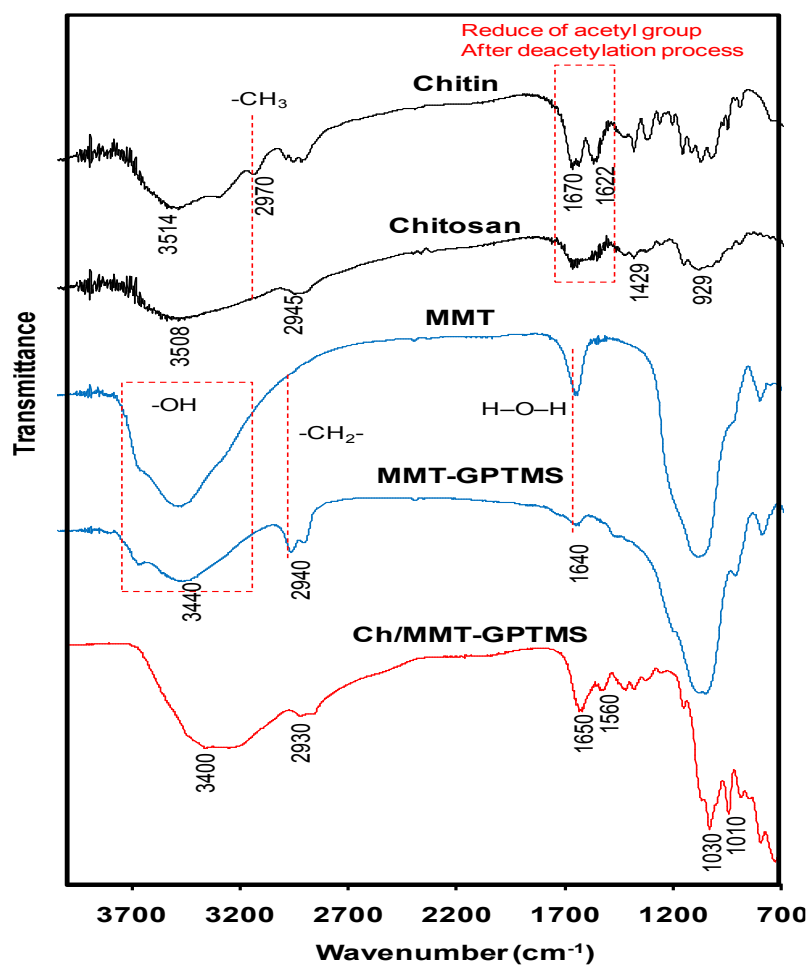

Figure 1. FTIR spectra of MMT, MMT-GPTMS, Chitin, Chitosan and Ch/MMT-GPTMS composite membrane 
The filler modification process is illustrated in Figure 2(a). The modification process starts with hydrolysis of the three labile metoxy groups attached to silicon atom. The - $\mathrm{OH}$ group for the hydrolysis process was contributed by water present on the MMT surface. Then, a reactive silanol group is formed, which can bind together with other silanol groups to be oligomers at condensation step. The third step is to attach the oligomers via hydrogen bonding with $-\mathrm{OH}$ groups on MMT surface. Finally, termination reaction of epoxy groups with $\mathrm{HCl}$ acid solution catalytic, resulting in hydroxyl group formation at the end side of GPTMS[37,38].

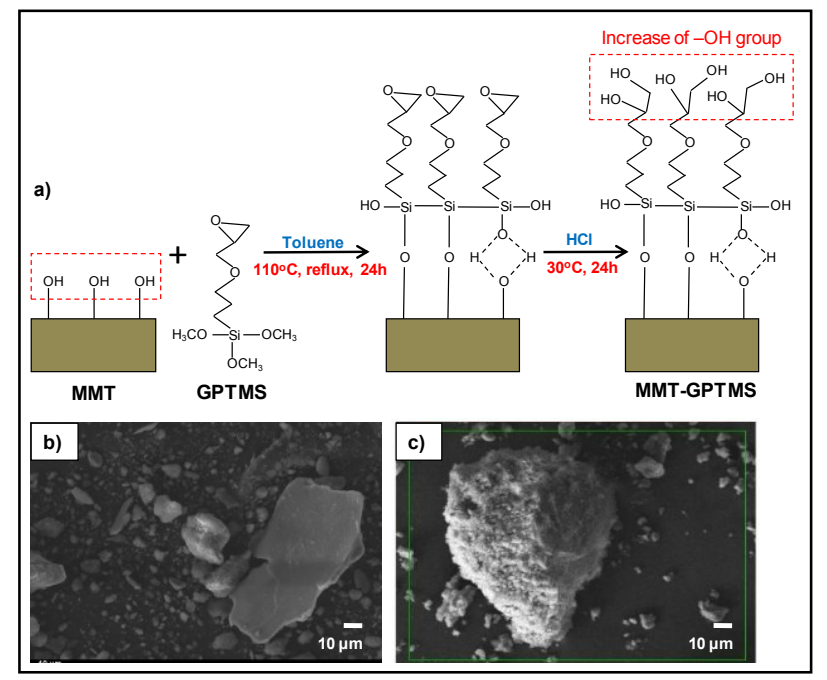

Figure 2. Illustration scheme of MMT modification process by GPTMS (a) and SEM image (b) MMT and (c) MMT-GPTMS

Figure $2(b, c)$ shows the SEM images for MMT and MMT-GPTMS surface. The MMT surfaces are smooth and flat, but after the modification process, the MMT-GPTMS surface becomes rough and overgrown soft granules are spread almost evenly on the MMT-GPTMS surface (Figure 2b). This indicates that GPTMS has been successfully incorporated on the surface of MMT, showing good interlocking interaction. SEM and FTIR results confirmed that the MMT particles were successfully modified using GPTMS to form MMT-GPTMS filler.

Physicochemical and thermal stability of membrane

The FTIR spectra of Ch/MMT-GPTMS composite membrane presented in Figure 1. Two peaks at $3400 \mathrm{~cm}^{-1}$ and $1650 \mathrm{~cm}^{-1}$ which are attributed to hydroxyl group and amide groups, indicating that the characteristics of chitosan still exist as a matrix in composite membrane. The peaks at $2930 \mathrm{~cm}^{-1}$ were assigned to $-\mathrm{CH}_{2}$ stretching, and the two bands at $1030 \mathrm{~cm}^{-1}$ and $1010 \mathrm{~cm}^{-1}$ for chitosan matrix were merged and shifted towards $1030 \mathrm{~cm}^{-1}$ in MMTGPTMS filled composite membranes due to the overlapping of $\mathrm{Si}-\mathrm{O}$ band with the $\mathrm{C}-\mathrm{O}$ stretching band [16].The $\mathrm{SEM}$ images for pure chitosan membrane, $\mathrm{Ch} / \mathrm{MMT}$ and $\mathrm{Ch} / \mathrm{MMT}$-GPTMS composite membrane are presented in Figure 3.

As can be seen in Figure 3(a), the pure chitosan membrane shows a void free dense structure. Meanwhile, Figure 3(b) shows the MMT agglomeration between the chitosan polymer matrix, which is due to the incompatibility between inorganic and organic material. Better interfacial morphology was able to be achieved after the MMT modification using GPTMS, thus improving the compatibility between chitosan organic polymer and MMTGPTMS inorganic filler, and reducing the MMT-GPTMS agglomeration, as shown in Figure 3(c) $[33,38]$. The incompatibility between chitosan organic polymer and MMT inorganic filler has caused the phase separation in Ch/MMT 5 membrane, thus the agglomeration of MMT particles are formed (Figure 3(e)). However, the crosssection image of $\mathrm{Ch} / \mathrm{MMT}$-GPTMS 5 shows that the MMT-GPTMS filler was well dispersed inside the chitosan 
polymer matrices with no visible agglomeration occurred (Figure 3(f)). This proves that the addition of GPTMS on the surface of MMT filler was able to increase the compatibility between the chitosan matrix and MMT-GPTMS filler.
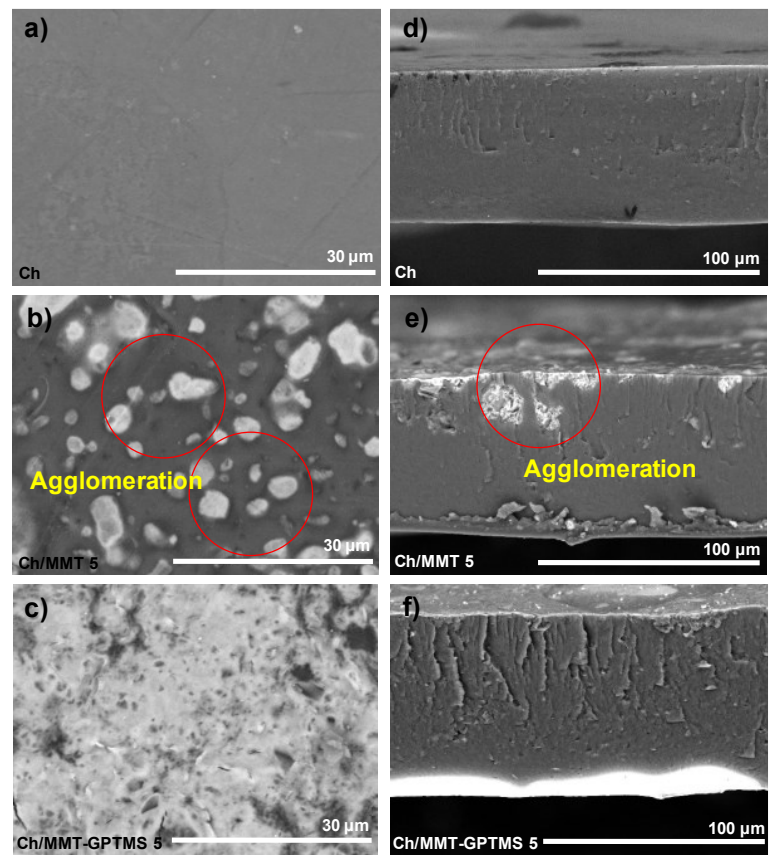

Figure 3. SEM images of (a) pristine Ch, (b) Ch/MMT, and (c) Ch/MMT-GPTMS membrane, (d), (e), and (f) showed the cross section of chitosan, $\mathrm{Ch} / \mathrm{MMT}$ and $\mathrm{Ch} / \mathrm{MMT}-\mathrm{GPTMS}$ membrane, respectively

The TGA analysis was carried out to evaluate the thermal stability of the pure chitosan, $\mathrm{Ch} / \mathrm{MMT}$ and $\mathrm{Ch} / \mathrm{MMT}$ GPTMS. The TGA and DTG curves in Figure4 show that all membranes followed almost identical degradation mechanism since there were miniscule difference in $T_{10 \%}, T_{30 \%}, T_{50 \%}$, and $T_{\max }$, as shown in Table 1. As shown in the Figure 4 all membranes show three stages of weight loss, the first stage that happens below $175{ }^{\circ} \mathrm{C}$ which was attributed to the evaporation of absorbed water[14,39]. The second stage happens at $175-400{ }^{\circ} \mathrm{C}$ interval because of the chitosan polymer chain degradation, and the last stage happens after $400{ }^{\circ} \mathrm{C}$ due to the decomposition of residual organic group [31]. It has been reported that the decomposition of montmorillonite clay is not complete until $800{ }^{\circ} \mathrm{C}$ [39]. Therefore, it is believed that the incorporation of inorganic filler might fill the gaps between the chitosan polymer matrixes, thus making the chain becomes tighter and increases the strength of the chitosan polymer chain. This occurrence might attribute to the increasing of thermal stability characteristics of $\mathrm{Ch} / \mathrm{MMT}$ and Ch/MMT-GPTMS membrane compared to its parent chitosan membrane as shown in Figure 4. As can be seen in Table 1, the neat chitosan exhibited the lowest in residual percent, while the Ch/MMT-GPTMS exhibited the higest. The incorporation of GPTMS has improved the interaction of MMT with chitosan by introducing more functional groups, so increasing of thermal stability of $\mathrm{Ch} / \mathrm{MMT}$-GPTMS composite membrane. These results are in good agreement with previously reported values for chitosan composites [14].

Furthermore, Figure 4 suggested that the Ch/MMT-GPTMS membrane has lower weight loss percentage compared to the $\mathrm{Ch} / \mathrm{MMT}$ membrane. The greater hydrogen bond formation was expected in Ch/MMT-GPTMS membrane rather than in Ch/MMT membrane (As can be illustrated in Figure 5(a) and (b)). Thus, the greater hydrogen bonding formation would improve the interaction of MMT filler within chitosan polymer matrices. Consequently, the 
Purwanto et al: CORRELATION BETWEEN PROTON CONDUCTIVITY, HYDROPHILICITY, AND

THERMAL STABILITY OF CHITOSAN/MONTMORILLONITE COMPOSITE MEMBRANE MODIFIED GPTMS AND THEIR PERFORMANCE IN DIRECT METHANOL FUEL CELL

$\mathrm{Ch} / \mathrm{MMT}$-GPTMS membrane becomes tighter and stronger than $\mathrm{Ch} / \mathrm{MMT}$ membrane, thus giving the $\mathrm{Ch} / \mathrm{MMT}$ GPTMS membrane higher thermal stability characteristics compared to $\mathrm{Ch} / \mathrm{MMT}$ membrane.

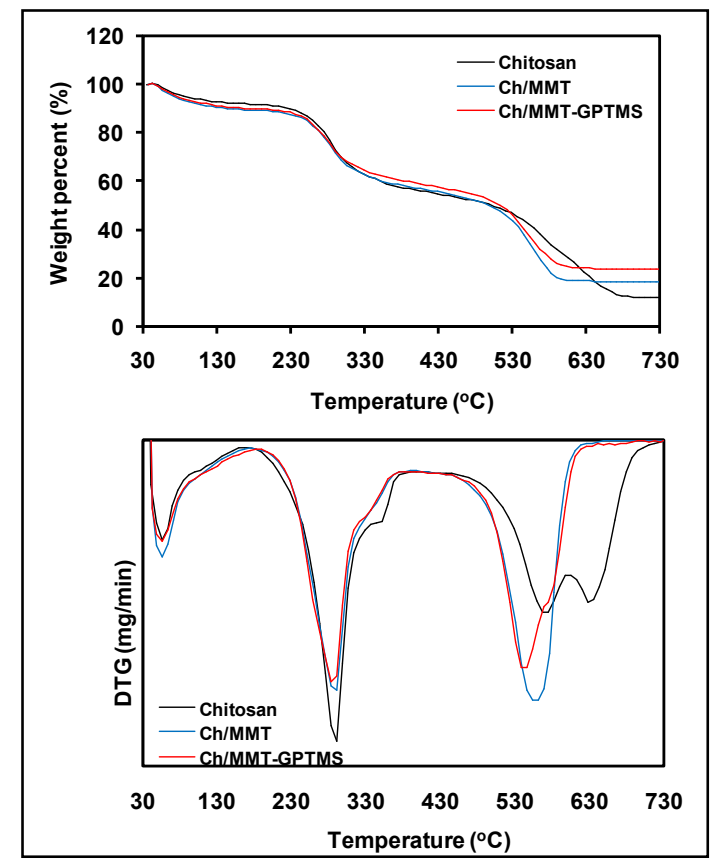

Figure 4. TGA and DTG curves for pristine chitosan, $\mathrm{Ch} / \mathrm{MMT}$, and Ch/MMT-GPTMS membrane.

Table 1. Thermal Stability Data of Ch, Ch/MMT, and Ch/MMT-GPTMS composite membrane

\begin{tabular}{|c|c|c|c|c|c|c|c|}
\hline \multirow[t]{2}{*}{ Sample } & \multirow{2}{*}{$\begin{array}{c}\mathrm{T}_{10} \% \\
\left({ }^{\circ} \mathrm{C}\right)\end{array}$} & \multirow{2}{*}{$\begin{array}{c}\mathrm{T}_{30} \% \\
\left({ }^{\circ} \mathrm{C}\right)\end{array}$} & \multirow{2}{*}{$\begin{array}{c}\mathrm{T}_{50} \% \\
\left({ }^{\circ} \mathrm{C}\right)\end{array}$} & \multicolumn{3}{|c|}{ DTG peak, $T_{\max }\left({ }^{\circ} \mathrm{C}\right)$} & \multirow{2}{*}{$\begin{array}{l}\text { Residue at } \\
730{ }^{\circ} \mathrm{C}(\%)\end{array}$} \\
\hline & & & & $T_{\max }{ }^{1}$ & $T_{\max }^{2}$ & $T_{\max }{ }^{3}$ & \\
\hline Chitosan & 220.9 & 298.4 & 500.9 & 56.4 & 290.6 & 575.7 & 12.1 \\
\hline $\mathrm{Ch} / \mathrm{MMT}$ & 122.2 & 290.3 & 498.5 & 56.3 & 290.3 & 561.7 & 18.9 \\
\hline $\mathrm{Ch} / \mathrm{MMT}$-GPTMS & 144.6 & 298.1 & 514.5 & 56.4 & 290.3 & 546.3 & 23.8 \\
\hline
\end{tabular}

Similar observations also have been reported by Wang and co-worker with CS/Zeolite and CS/Zeolite-GPTMS composite membrane [31]. In their study, the CS/Beta-GPTMS membrane showed a little higher thermal stability than the CS/Beta membrane. It has been suggested that the organic chains and $-\mathrm{OH}$ groups on the surface of the GPTMS-modified zeolite beta particles can enhance the interactions between the zeolite beta and chitosan molecules, which decelerate the decomposition of the chitosan main chain. Wang and co-workers had reported the strong interaction of MMT filler in the CS matrix to form flocculated structure in $\mathrm{Ch} / \mathrm{MMT}$ composite. Since one chitosan unit possesses one amino and two hydroxyl functional groups, these functional groups can form hydrogen bonds with the silicate hydroxylated edge groups from montmorillonite filler, which lead to the strong interaction between matrix and MMT layers [40]. The same phenomenon of interaction polymer clay composite has been reported [41], the layer of biopolymer is adsorbed by means of a hydrogen bonding mechanism, since the hydroxyl functional groups in surface of the MMT has been already balanced by functional groups of the chitosan layer as a matrix. 


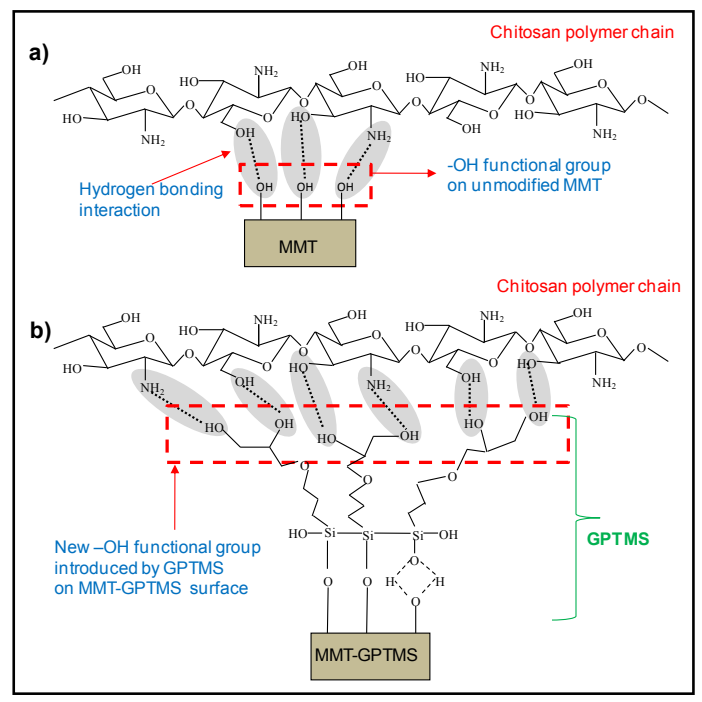

Figure 5. Plausible schematic diagram illustrates the bonding formation between chitosan parent polymer and its filler for (a) Ch/MMT and(b) Ch/MMT-GPTMS composite membranes

\section{Water uptake, membrane swelling and hydrophilic properties}

The hydrophilic property of membrane was studied based on water contact angle (WCA), water uptake (WU) and membrane swelling (MS). The water uptake has a profound effect on proton transport and dimensional stability of proton conducting membranes. The high water uptake is favorable for high performance PEM to facilitate great numbers of protons hopping and diffusion through the membrane. The water uptake and membrane swelling for chitosan, $\mathrm{Ch} / \mathrm{MMT}$ and $\mathrm{Ch} / \mathrm{MMT}-\mathrm{GPTMS}$ is shown in Table 2. The water uptake for pure chitosan membrane is $72.9 \%$, after the incorporated of inorganic filler the water uptake decreased at $54.5 \%$ and $62.1 \%$ for $\mathrm{Ch} / \mathrm{MMT}$ and Ch/MMT-GPTMS, respectively. The similar trend has been reported in previous study, the water uptake for $\mathrm{Ch} /$ Zeolite composite membrane showed a decrease as the zeolite filler load increased [31]. In addition, Madaeni and co-worker reported in previous study where the water uptake for PVA composite membrane decreased by incorporated filler [42].

Table 2. Water uptake and membrane swelling for chitosan, Ch/MMT and Ch/MMT-GPTMS

\begin{tabular}{lcc}
\hline Membrane & $\begin{array}{c}\text { Water Uptake } \\
\text { (\%) }\end{array}$ & $\begin{array}{c}\text { Membrane Swelling } \\
\text { (\%) }\end{array}$ \\
\hline Chitosan & 72.9 & 23.7 \\
Ch/MMT 5 & 54.5 & 18.5 \\
Ch/MMT-GPTMS 5 & 62.1 & 19.7 \\
Ch/MMT-GPTMS 10 & 53.9 & 18.1 \\
Ch/MMT-GPTMS 15 & 49.2 & 17.9 \\
\hline
\end{tabular}

The high water uptake of chitosan membrane showing better hydrophilic trend, compared to $\mathrm{Ch} / \mathrm{MMT}$ composite membrane which presence decreased the water uptake. This phenomenon suggested to the dynamic water contact angle of pristine chitosan and Ch/MMT 5 composite membrane are plotted in Figure 6. It was found that the initial contact angle of pristine chitosan showed a better hydrophilicity than Ch/MMT $5\left(35.9^{\circ}\right.$ compared to $\left.82.8^{\circ}\right)$. This results established that lower contact angle showed a better hydrophilicity, thus notably indicating that hybrid 
membrane presented an enhanced hydrophilicity or decrease of hydrophilicity depends to addition inorganic filler $[31,42,43]$.

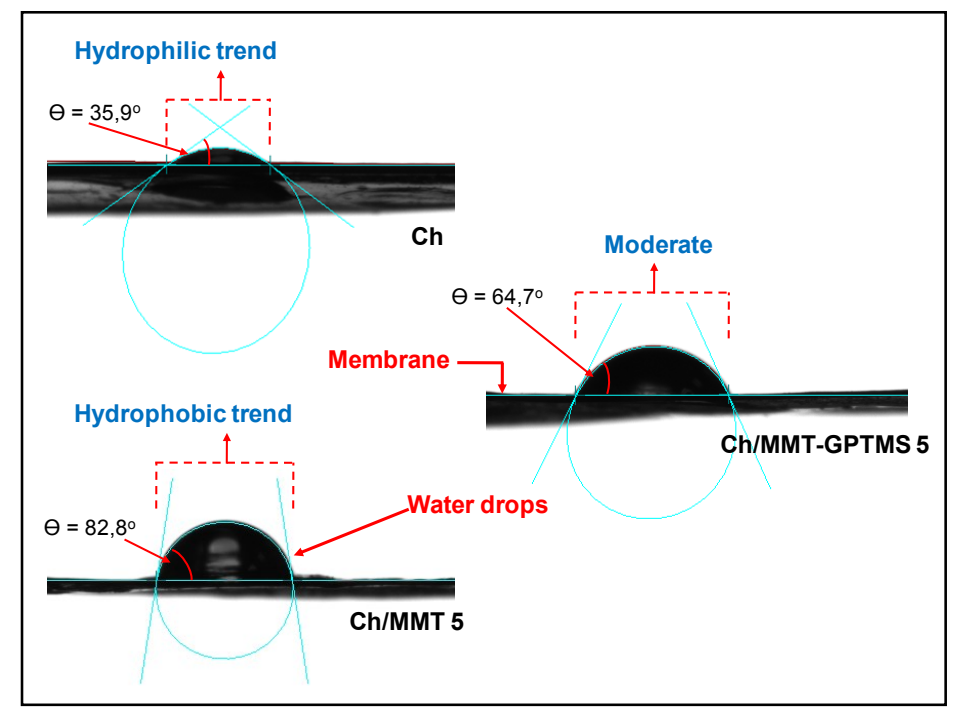

Figure 6. Water contact angle $\mathrm{Ch}, \mathrm{Ch} / \mathrm{MMT}$ and $\mathrm{Ch} / \mathrm{MMT}$-GPTMS

In another part, for direct methanol fuel cell application, membrane with high hydrophilic properties are very crucial to be able to hold existence of water because the proton will be transported along the water channel created in the membrane composite, however the hydrophobic properties also crucial to reduce methanol permeation rate which causes decrease of membrane efficiency. Therefore the moderate membrane is very suitable for this application, for get high proton conductivity and low methanol permability as previous study [31,38]. Thus, in this study, we were able to prepare composite membrane with moderate properties, Ch/MMT-GPTMS 5 with water uptake at $62 \%$, suggested to the equilibrium water contact angle, at $64.7^{\circ}$ (Figure 6).

As seen as Table 2, shows the water uptake as a function of the membrane swelling of the chitosan, $\mathrm{Ch} / \mathrm{MMT}$ and Ch/MMT-GPTMS membranes. As compared to pristine chitosan, high water uptake values were characterized for $\mathrm{Ch} / \mathrm{MMT}$ and Ch/MMT-GPTMS composite membranes, but all of them showed low membrane swelling. The targeted membranes should be modest water uptake values and low membrane swelling ratios. These results revealed that the role of surface modification by GPTMS in Ch/MMT-GPTMS composite can be expected to possess higher thermal stability characteristics and lower membrane swelling, compared to pure $\mathrm{Ch}$ and $\mathrm{Ch} / \mathrm{MMT}$ membrane. Therefore, the resultant composite membrane is stable at desired operating temperatures $\left(<100{ }^{\circ} \mathrm{C}\right)$ for DMFCs application.

\section{Proton conductivity, methanol permeability and DMFC performance}

Proton conductivity is one of the most essential requirement to enable membranes to be applicable in DMFC. The efficiency of the proton transfer within the PEM is therefore related either as water solvated species or the number of ionic sites, polymer functional groups and microstructure formation in the PEM through the interconnection between proton-conductive channels/species in the membranes [44]. The proton conductivity for chitosan and composite membranes are listed in Table 3 . As seen as Table 3, the proton conductivity of hydrated plain chitosan membrane was $2.4 \mathrm{mS} \mathrm{cm}^{-1}$ and increase with incorporated of MMT loading 5\% in composite membrane, at 2.7 $\mathrm{mScm}^{-1}$. The composite membrane $\mathrm{Ch} / \mathrm{MMT}$-GPTMS 5 is able to achieve maximum proton conductivity of 4.7 $\mathrm{mScm}^{-1}$, an increase from $2.7 \mathrm{mScm}^{-1}$ exhibited by the Ch/MMT 5. The phenomenon can be explained that, the surface modification of MMT using GPTMS make an increase of hydroxy group, thus it can improve interaction 
between the -OH group of MMT-GPTMS filler with hydroxy group and amine group of biopolymer chitosan via hydrogen bonding. High interaction in membrane structure provides additional conduction site for proton to be transported, thus increases the proton conductivity of the membrane.

Table 3. Proton conductivity and methanol permeability for chitosan, Ch/MMT and Ch/MMT-GPTMS

\begin{tabular}{lcc}
\hline Membrane & $\begin{array}{c}\text { Proton Conductivity } \\
\left(\mathbf{m S c m} \mathbf{m s}^{-1}\right)\end{array}$ & $\begin{array}{c}\text { Methanol Permeability } \\
\left(\mathbf{x ~ 1 0}^{-7} \mathbf{c m}^{\mathbf{2}} \mathbf{~ s}^{-1}\right)\end{array}$ \\
\hline Chitosan & 2.4 & 4.9 \\
Ch/MMT 5 & 2.7 & 4.7 \\
Ch/MMT-GPTMS 5 & 4.7 & 3.0 \\
Ch/MMT-GPTMS 10 & 4.3 & 3.2 \\
Ch/MMT-GPTMS 15 & 4.1 & 7.6 \\
\hline
\end{tabular}

Ch, MMT and GPTMS are able to establish channels of hydrophilic or water bulk phase which allows the protons to be transported via vehicle mechanism in the form of hydronium ions [44-46]. It has been suggested that, electrostatic interaction in the membranes which contain the abbundance hydroxy group and presence of $-\mathrm{NH}_{3}{ }^{+}$ allows the proton transferred along the ionic bonds and hydrogen bonds by "jumping" from one functional group to another. The incorporation of modified MMT (MMT-GPTMS) within the chitosan matrix has given chance for more protons to transport in $\mathrm{Ch} / \mathrm{MMT}$-GPTMS membrane, so that the proton conductivity of the membrane is higher than the Ch/MMT membrane. However, higher filler load had led to agglomerations problem in composite membrane, hence reduce of both water content and effectiveness of filler to provide conduction site for proton at the same time, thus decrease the proton conductivity of the membrane. The proton conductivity decrease after $10 \%$ loading filler at $4.3 \mathrm{mScm}^{-1}$ and $4.1 \mathrm{mScm}^{-1}$ for Ch/MMT-GPTMS 10 and Ch/MMT-GPTMS 15, respectively (Table 3 ). This results established that a better hydrophilicity and high thermal stability are important characteristics to be able to hold water and reduce of hidration phenomenon. The proton will be transported along the water channel created in the membrane composite by hydronium ions. The existence of water has a profound effect on proton transport and dimensional stability of proton conducting membranes.

The methanol permeability of the chitosan and composite membranes at room temperature is shown in Table 3 . The role of GPTMS for MMT modification process in composite membranes exhibited low methanol permeability until $3.0 \times 10^{-7} \mathrm{~cm}^{2} \mathrm{~s}^{-1}$ for $\mathrm{Ch} / \mathrm{MMT}$-GPTMS 5. This results lower than that of pristine chitosan $\left(4.9 \times 10^{-7} \mathrm{~cm}^{2} \mathrm{~s}^{-1}\right)$ and Ch/MMT $\left(4.7 \times 10^{-7} \mathrm{~cm}^{2} \mathrm{~s}^{-1}\right)$. It is suggested that, existense of GPTMS attributed hydrophobic characterstic in morphology membrane structure, shown incline hydrophobicity with increasing of initial contac angle (Figure 6), and in the other hand the MMT-GPTMS structure that has a quite wide and long ratio which creates longer diffusion path for methanol permeate [47]. The methanol permeability of Ch/MMT-GPTMS is obtained the lowest with the MMT-GPTMS filler loading at 5\%, but increased slightly with $10 \%$ filler load, then an increase in the permeability of methanol is significant when the filler loading was increased to $15 \%$. This phenomenon can be explained that, the matrix and filler need good collaboration with a specific composition, especially with addition of GPTMS included in the layer structure of the membrane can support the interaction between the inorganic filler and biopolymer matrix. Therefore, the precise composition of composite membrane will have a good structure, more dense and has the ability to reduce of methanol diffusion. The increase of the methanol permeability of Ch/MMT-GPTMS 15 more than a double of $\mathrm{Ch} / \mathrm{MMT}$-GPTMS 10 is due to the excess of filler load showing a low interaction distribution in membrane structure, therefore it caused agglomeration. This phenomenon led to the presence of pin hole in the composite membrane, which provide greater opportunities for methanol to diffuse into the membrane structure, thus the methanol permeability is significanly increased. The similar trend also can be found in previous study [31].

The DMFC responses of $\mathrm{Ch} / \mathrm{MMT}-\mathrm{GPTMS}$ composite membrane compared with $\mathrm{Ch} / \mathrm{MMT}$ at room temperature with $2 \mathrm{M}$ methanol consentrations and oxygen flow at the $2 \mathrm{~mL} / \mathrm{min}$ is represented in Figure 7 . The cell performance 
based on Ch/MMT composite membrane in terms of power density was $5.01 \times 10^{-2} \mathrm{~mW} / \mathrm{cm}^{2}$, and increase of the cell performance for Ch/MMT-GPTMS until $24.87 \times 10^{-2} \mathrm{~mW} / \mathrm{cm}^{2}$. Clearly, the higher cell performance based on $\mathrm{Ch} / \mathrm{MMT}$-GPTMS membrane was attributed to the fact that more hydrogen bonding and water content to achieve proton conductivity comparable to Ch/MMT-GPTMS because the hydrophilic characteristics. In the Ch/MMTGPTMS composite membrane, the proton transport can occur from $\mathrm{H}_{3} \mathrm{O}^{+}$as proton donor to $\mathrm{H}_{2} \mathrm{O}$ as acceptor on the membrane structure. Uniform distribution and optimum water content within the composite membrane is critical for the continuous proton transfer pathway with minimum resistance.

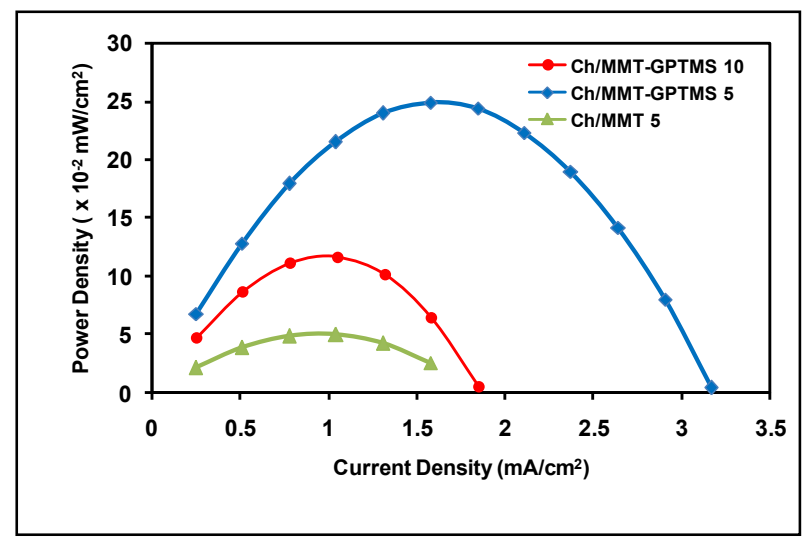

Figure 7. DMFC performance of composite membrane

\section{Conclusion}

A composite membrane was obtained through using solution casting method, and GPTMS was introduced into the system to increase of matrix and filler interaction. The properties of the composite membranes, such as thermal stability, hydrophilicity and proton conductivity were significantly improved. The Ch/MMT-GPTMS showed excellent proton conductivities varying from 4.1 to $4.7 \mathrm{mS} \mathrm{cm}^{-1}$ at $25{ }^{\circ} \mathrm{C}$, which are higher compared to pristine chitosan and $\mathrm{Ch} / \mathrm{MMT}$. The $\mathrm{Ch} / \mathrm{MMT}$-GPTMS composite membrane with $5 \mathrm{wt} \%$ filler load exhibited the best proton conductivity are $4.7 \mathrm{mScm}^{-1}$, with water contact angle value of $64.7^{\circ}$ and shown maximum power density of $0.24 \mathrm{mWcm}^{-2}$ was obtained with a $2 \mathrm{M}$ methanol feed. In this study it was known that water contact angle, membrane swelling, thermal stability, and proton conductivity show suitable trend, it means that all quality of them are related to the hydrophilicity properties.

\section{Acknowledgement}

The author (Mochammad Purwanto) would like to express gratitude to the Ministry of Science, Technology and Innovation (MOSTI) Malaysia for the grants with vote number of R.J130000.7809.4F592, Q.J130000.2509.05H52 and R.J130000.7942.4S507 for the financial support and to the research management centre (RMC), UTM for supporting related research management activities.

\section{References}

1. Yuan, T., Pu, L., Huang, Q., Zhang, H., Li, X. and Yang H. Yang. (2014). An effective methanol-blocking membrane modified with graphene oxide nanosheets for passive direct methanol fuel cells. Electrochimica Acta, 117: 393 - 397.

2. Sadrabadi, M. M. H., Dashtimoghadam, E., Majedi, F. S., Kabiri, K., Solati-Hashjin, M. and Moaddel, H. (2010). Novel nanocomposite proton exchange membranes based on Nafion and AMPS-modified montmorillonite for fuel cell applications. Journal of Membrane Science, 365(1-2): 286 -293.

3. Cui, Z., Xing, W., Liu, C., Liao, J. and Zhang, H. (2009). Chitosan/heteropolyacid composite membranes for direct methanol fuel cell. Journal of Power Sources, 188(1): 24 - 29. 
4. Jung, D. H., Cho, S. Y., Peck, D. H., Shin, D. R. and Kim, J. S. (2003). Preparation and performance of a Nafion/montmorillonite nanocomposite membrane for direct methanol fuel cell. Journal of Power Sources. 118(1-2): $205-211$.

5. Lu, J. L., Fang, Q. H., Li, S. L. and Jiang, S. P. (2013). A novel phosphotungstic acid impregnated meso-Nafion multilayer membrane for proton exchange membrane fuel cells. Journal of Membrane Science, 427: 101 - 107.

6. Lufrano, F., Baglio, V., Staiti, P., Antonucci, V., and Arico, A. S. (2013). Performance analysis of polymer electrolyte membranes for direct methanol fuel cells. Journal of Power Sources, 243: 519 -534.

7. Wang J. and Wang, L. (2014). Preparation and properties of organic-inorganic alkaline hybrid membranes for direct methanol fuel cell application. Solid State Ionics, 255: 96 - 103.

8. Younes, I., Ghorbel-Bellaaj, O., Nasri, R., Chaabouni, M., Rinaudo, M. and Nasri, M. (2012). Chitin and chitosan preparation from shrimp shells using optimized enzymatic deproteinization. Process Biochemistry, 47(12): $2032-2039$.

9. Sagheer, F. A., Al-Sughayer, M. A., Muslim, S. and Elsabee, M. Z. (2009). Extraction and characterization of chitin and chitosan from marine sources in Arabian Gulf. Carbohydrate Polymer, 77(2): 410 - 419.

10. Chatterjee, S., Adhya, M., Guha, A. K. and Chatterjee, B. P. (2005). Chitosan from Mucor rouxii: production and physico-chemical characterization. Process Biochemistry, 40(1): $395-400$.

11. Krishna Rao, K. S. V., Ramasubba Reddy, P., Lee, Y.-I, and Kim, C. (2012). Synthesis and characterization of chitosan-PEG-Ag nanocomposites for antimicrobial application. Carbohydrate Polymer, 87(1): 920 - 925.

12. Croisier, F. and Jérôme, C. (2013). Chitosan-based biomaterials for tissue engineering. European Polymer Journal, 49(4): $780-792$.

13. Bhattacharyya, R. and Ray, S. K. (2014). Micro- and nano-sized bentonite filled composite superabsorbents of chitosan and acrylic copolymer for removal of synthetic dyes from water. Applied Clay Science, 101: 510 520 .

14. Lewandowska, K., Sionkowska, A., Kaczmarek, B. and Furtos, G. (2014). Characterization of chitosan composites with various clays. International Journal of Biological Macromolecules, 65: $534-541$.

15. Liu, Y., Yang, S. and Niu, W. (2013). Simple, rapid and green one-step strategy to synthesis of graphene/carbon nanotubes/chitosan hybrid as solid-phase extraction for square-wave voltammetric detection of methyl parathion. Colloids Surface B: Biointerfaces. 108: 266 - 270.

16. Olad, A. and Farshi Azhar, F. (2014). The synergetic effect of bioactive ceramic and nanoclay on the properties of chitosan-gelatin/nanohydroxyapatite-montmorillonite scaffold for bone tissue engineering. Ceramic International, 40(7): $10061-10072$.

17. El Ichi, S., Zebda, A., Alcaraz, J. P., Laaroussi, A., Boucher, F., Boutonnat, J., Reverdy-Bruas, N., Chaussy, D., Belgacem, M. N., Cinquin, P. and Martin, D. K. (2015). Bioelectrodes modified with chitosan for long-term energy supply from the body. Energy and Environmental Science, 8(3): $1017-1026$.

18. Sabaa, M. W., Abdallah, H. M., Mohamed, N. A. and Mohamed, R. R. (2015). Synthesis, characterization and application of biodegradable crosslinked carboxymethyl chitosan/poly(vinyl alcohol) clay nanocomposites. Materials Science and Engineering C, 56: 363 - 373.

19. Petersson, L., Kvien, I. and Oksman, K. (2007). Structure and thermal properties of poly(lactic acid)/cellulose whiskers nanocomposite materials. Composite Science Technology, 67(11-12): 2535 -2544.

20. Mohamed, M. A., Salleh, W. N. W., Jaafar, J., Ismail, A. F., Mutalib, M. A, Sani, N. A. A., Asri, S. E. A. M. and Ong, C. S. (2016). Physicochemical characteristic of regenerated cellulose/N-doped $\mathrm{TiO}_{2}$ nanocomposite membrane fabricated from recycled newspaper with photocatalytic activity under UV and visible light irradiation. Chemical Engineering Journal, 284: 202 - 215.

21. Grigoriadi, K., Giannakas, A., Ladavos, A. K. and Barkoula, N. M. (2015). Interplay between processing and performance in chitosan-based clay nanocomposite films. Polymer Bulletin, 72(5): $1145-1161$.

22. Huang, Y., Huang, J., Cai, J., Lin, W., Lin, Q., Wu, F. and Luo, J. (2015). Carboxymethyl chitosan/clay nanocomposites and their copper complexes: Fabrication and property. Carbohydrate Polymer, 134: 390 - 397.

23. Hong, S. I., Lee, J. H., Bae, H. J., Koo, S. Y., Lee, H. S., Choi, J. H., Kim, D. H., Park, S.-H. and Park, H. J. (2011). Effect of shear rate on structural, mechanical, and barrier properties of chitosan/montmorillonite nanocomposite film. Journal of Applied Polymer Science, 119(5): 2742 -2749.

24. Oguzlu, H. and Tihminlioglu, F. (2010). Preparation and barrier properties of chitosan-layered silicate nanocomposite films. Macromolecule Symposium, 298 (1): 91 - 98. 
Purwanto et al: CORRELATION BETWEEN PROTON CONDUCTIVITY, HYDROPHILICITY, AND THERMAL STABILITY OF CHITOSAN/MONTMORILLONITE COMPOSITE MEMBRANE MODIFIED GPTMS AND THEIR PERFORMANCE IN DIRECT METHANOL FUEL CELL

25. Ludueña, L., Morán, J. and Alvarez, V. (2015). Biodegradable polymer/claynanocomposites. in eco-friendly polymer nanocomposites, $75^{\text {th }}$ Edition, V. K. Thakur and M. K. Thakur, Eds. Springer India. pp. $109-135$.

26. Liu, X., Hu, M. and Hu, Y. (2008). Chemical composition and surface charge properties of montmorillonite. Journal of Central South University Technology, 15(2): 193 - 197.

27. Zhu, J., Tian, M., Zhang, Y., Zhang, H. and Liu., J. (2015). Fabrication of a novel 'loose' nanofiltration membrane by facile blending with Chitosan-Montmorillonite nanosheets for dyes purification. Chemical Engineering Journal, 265: 184 - 193.

28. Liu, B., Wang, X., Yang, B. and Sun, R. (2011). Rapid modification of montmorillonite with novel cationic Gemini surfactants and its adsorption for methyl orange. Materials Chemistry and Physics, 130(3): 1220 1226.

29. Huskić, M., Brnardić, I., Žigon, M. and Ivanković, M. (2008). Modification of montmorillonite by quaternary polyesters. Journal of Non Crystalline Solids, 354(28): 3326 - 3331.

30. Jiratumnukul, N., Manowanna, P. and Premmag, N. (2012). Modified bentonite clay in UV-curable coating applications. Engineering Journal, 16(3): 13 - 18.

31. Wang, Y., Jiang, Z., Li, H., and Yang, D. (2010). Chitosan membranes filled by GPTMS-modified zeolite beta particles with low methanol permeability for DMFC. Chemistry Engineering Process, Process Intensification, 49(3): $278-285$.

32. Trisnawati, E., Andesti, D. and Saleh, A. (2013). Pembuatan kitosan dari limbah cangkang kepiting sebagai bahan pengawet buah duku dengan variasi lama pengawetan. Jurnal Teknologi Kimia, 19(2): 17 - 26.

33. Wang, Y., Yang, D., Zheng, X., Jiang, Z. and Li, J. (2008). Zeolite beta-filled chitosan membrane with low methanol permeability for direct methanol fuel cell. Journal Power Sources, 183(2): 454 - 463.

34. Tohidian, M., Ghaffarian, S. R., Shakeri, S. E., Dashtimoghadam, E. and Hasani-Sadrabadi, M. M. (2013). Organically modified montmorillonite and chitosan-phosphotungstic acid complex nanocomposites as high performance membranes for fuel cell applications.Journal of Solid State Electrochemistry, 17(8): 2123 - 2137.

35. Cui, Z., N. Li, X. Zhou, C. Liu, J. Liao, S. Zhang and W. Xing. (2007). Surface-modified Nafion membrane by casting proton-conducting polyelectrolyte complexes for direct methanol fuel cells. Journal of Power Sources, 173(1): $162-165$.

36. Kumari, S. and Rath, P. K. (2014). Extraction and characterization of chitin and chitosan from (Labeo rohit) fish scales. Procedia Materials Science, 6: 482 - 489.

37. Duan, J. K., Shao, S. X., Jiang, L., Li, Y., Jing, P. K. and Liu, B. P. (2011). Nano-attapulgite functionalization by silane modification for preparation of covalently-integrated epoxy/TMPTMA Nanocomposites. Iranian Polymer Journal, 20(11): $855-872$.

38. Wu, H., Zheng, B., Zheng, X., Wang, J., Yuan, W. and Jiang, Z. (2007). Surface-modified Y zeolite-filled chitosan membrane for direct methanol fuel cell. Journal of Power Sources, 173(2): 842 - 852.

39. Dos Santos, B. R., Bacalhau, F. B., Pereira, T. D. S., Souza, C. F. and Faez, R. (2015). Chitosanmontmorillonite microspheres: A sustainable fertilizer delivery system. Carbohydrate Polymer, 127: 340 - 346.

40. Wang, S. F., Shen, L., Tong, Y. J., Chen, L., Phang, I. Y., Lim, P. Q. and Liu, T. X. (2005). Biopolymer chitosan/montmorillonite nanocomposites: Preparation and characterization. Polymer Degradation and Stability, 90(1): 123 - 131.

41. Darder, M., Colilla, M. and Ruiz-Hitzky, E. (2005). Chitosan-clay nanocomposites: Application as electrochemical sensors. Applied Clay Science, 28(1-4): 199 - 208.

42. Madaeni, S. S., Amirinejad, S. and Amirinejad, M. (2011). Phosphotungstic acid doped poly(vinyl alcohol)/poly(ether sulfone) blend composite membranes for direct methanol fuel cells. Journal of Membrane Science, 380(1-2): $132-137$.

43. Gosalawit, R., Chirachanchai, S., Shishatskiy, S. and Nunes, S. P. (2008). Sulfonated montmorillonite/sulfonated poly(ether ether ketone) (SMMT/SPEEK) nanocomposite membrane for direct methanol fuel cells (DMFCs). Journal of Membrane Science, 323(2): 337 - 346.

44. Lee, S. H., Choi, S. H., Gopalan, S. A., Lee, K. P. and Anantha-Iyengar, G. (2014). Preparation of new selfhumidifying composite membrane by incorporating graphene and phosphotungstic acid into sulfonated poly(ether ether ketone) film. International Journal of Hydrogen Energy, 39(30): 17162 -17177.

45. Xiao, Y., Xiang, Y., Xiu, R. and Lu, S. (2013). Development of cesium phosphotungstate salt and chitosan composite membrane for direct methanol fuel cells. Carbohydrate Polymer, 98(1): 233 - 240. 
46. Cui, Z., Liu, C., Lu, T. and Xing, W. (2007). Polyelectrolyte complexes of chitosan and phosphotungstic acid as proton-conducting membranes for direct methanol fuel cells. Journal of Power Sources, 167(1): 94 - 99.

47. Lin, H., Zhao, C. Ma, W., Shao, K., Li, H., Zhang, Y. and Na, H. (2010). Novel hybrid polymer electrolyte membranes prepared by a silane-cross-linking technique for direct methanol fuel cells. Journal of Power Sources, 195(3): $762-768$. 